\title{
Is Depression Associated with the Risk of Cardiovascular Disease or Vice Versa?
}

\author{
Erensu Baysak $^{1}$ (D), Feyza Aricioglu ${ }^{2}$ (D) \\ ${ }^{1}$ Marmara University, Faculty of Medicine, Department of Psychiatry, Istanbul, Turkey. \\ ${ }^{2}$ Marmara University, Faculty of Pharmacy, Department of Pharmacology and Psychopharmacology Research Unit, Istanbul, Turkey. \\ $\overline{\text { Correspondence Author: Feyza Aricioglu }}$ \\ E-mail: feyza.aricioglu@gmail.com \\ Received: $11.11 .2020 \quad$ Accepted: 04.12 .2020
}

\begin{abstract}
The comorbidity between cardiovascular disease (CVD) and depression has been observed for many years. Several biological and behavioral hypotheses have been proposed to explain this comorbidity. However, the underlying common mechanisms are still unclear. Evidence suggests a bidirectional relationship between depression and CVD. Inflammation has been implicated in the etiology of both depression and CVD. In this review, we aim to increase awareness for CVD and depression comorbidity and provide some insights about the possible role of inflammation.

Keywords: major depression; cardiovascular disease; inflammation; $h s$-CRP
\end{abstract}

\section{INTRODUCTION}

Major depressive disorder (MDD) is one of the most common psychiatric disorders and a leading cause of disability world wide which is characterized by depressed mood, anhedonia, impaired cognitive, motor, and physiological functions, feeling of worthlessness or excessive or inappropriate guilt, and recurrent thoughts of death (1). The specifiers of MDD according to DSM-5 (Diagnostic and Statistical Manual of Mental Disorders $5^{\text {th }}$ Edition) are severity, anxious distress, mixed features, melancholic features, psychotic features, peripartum onset, seasonal pattern (2). When the depressive symptoms do not meet the criteria for MDD, it is called subthreshold depression (3). Subthreshold depression has a considerable impact on the quality of life of patients and may be considered as a risk indicator of MDD (4).

Despiteadvancesinneuroscienceresearch, the pathophysiology of MDD has not been elucidated. The results of tremendous amount of research are consistent with a multifactorial etiology. Some of the suggested pathophysiological mechanisms are biological amine hypothesis, genetic and environmental factors, increased inflammation, the hypothalamic-pituitaryadrenal (HPA) axis abnormalities, decreased neurogenesis, and neuroplasticity (5).

Depression is associated with a significantly increased risk of cardiovascular morbidity and mortality (6). Cardiovascular diseases (CVD) and MDD are among the leading health problems worldwide $(7,8)$. It is known that CVD and MDD are the two most common causes of disability in high-income countries and are expected to become so for countries of all income levels by 2030 (9). A recent population-based cohort study demonstrated that depression was associated with incident CVD, myocardial infarction, non-cardiovascular death, and all-cause mortality in economically diverse settings, especially in urban areas (10). Approximately 35$40 \%$ of patients with CVD report depressive symptoms and depressive individuals have a 1.5 times higher risk of developing CVD than non-depressed controls (11). Many large-scale prospective studies have shown that MDD and even subthreshold depressive symptoms are an independent risk factor for CVD $(9,12-14)$. Standardized depression screening strategies should be provided in patients with CVD because early identification and optimal management of depression might improve health outcomes for these patients (15).

\section{DEPRESSION AS A RISK FACTOR FOR CVD}

The comorbidity between CVD and depression has been observed for many years, and studies argue that this relationship is bidirectional (16). In 1967, Wynn stated the relationship between unwarranted emotional stress and ischemic heart disease (17). The relationship between depression and CVD has been studied since the 1980s. In a cohort study included individuals with no history of ischemic heart disease or other serious medical illnesses at 
baseline, depressed affect and hopelessness were related to increased risk of fatal and nonfatal ischemic heart disease (18). The INTERHEART study conducted in 52 countries found that current smoking, raised Apolipoprotein B/ Apolipoprotein A1 ratio, history of diabetes, hypertension, and psychosocial factors (depression, perceived stress, and life events) were the strongest risk factors for myocardial infarction (19). The Framingham Study reported a direct association between depressive symptoms and all-cause mortality over 6 years of follow-up (20). A study assessed the prevalence of depression in patients with acute myocardial infarction (AMI) found that $19.8 \%$ of the patients were diagnosed with MDD according to the structured interview, and $31.1 \%$ of these patients were found to have clinically significant depressive symptoms according to the Beck Depression Inventory (21). AMI is associated with a previous hospitalization for depression and this association cannot be explained by confounding from known risk factors for AMI (22). In a ten-year follow-up study conducted with the clinically depressed patients and their matched community controls found that depressed patients had almost twothirds higher risk for physical illness, including cardiac problems compared to controls (23).

The Whitehall II study also stated that depression and increased resting heart rate are independent risk factors for death from all causes (24). In particular, anhedonia symptom of depression is the most strongly associated with cardiac events and mortality after AMI and the risk of CVD increased by 2.5 times in the year after the onset of MDD episode (25). A meta-analysis included prospective cohort studies evaluating the association between depression and the risk of CVD demonstrated that the depressed participants had an increased risk of $30 \%$ for CVD (26). Also, this association remained significant after the results were adjusted for the potential confounding factors. Furthermore, a study included young people who had a parent with depression but no personal history of depressive illness, found that the participants with a family history of depression had higher cardiovascular risk compared to healthy controls (27).

In 2014, the American Heart Association (AHA) announced that despite the heterogeneity of published studies depression is an independent risk factor for negative outcomes in patients with acute coronary syndrome (13).

\section{THE POSSIBLE ROLE OF INFLAMMATION IN COMORBIDITY}

The relationship between CVD and depression can be evaluated in three ways: First; these two conditions are comorbid, second; depression increases the risk of CVD or vice versa. Third; depression is an important indicator of poor prognosis in patients with CVD (28).

While the comorbidity between CVD and depression is well known, the underlying common mechanisms are still unclear. Several biological and behavioral hypotheses have been established including altered autonomic nervous system activity, low heart-rate variability, elevated catecholamine levels, endothelial dysfunction, platelet dysfunction, increased inflammatory activity, sedentary behavior, smoking, poor adherence to medication and diet $(9,16,29)$ (Figure 1). In recent years, the studies focused on the role of the immune system in the etiology of MDD and have shown increased pro-inflammatory cytokines in MDD (30-32). Similarly, the role of inflammation in CVD has attracted considerable attention and it has been determined that systemic inflammation has an important role in the development, progression, and prognosis of CVD (33).

Atherosclerosis is not considered as a simple "lipid deposition disease" anymore. For the past few decades, it has been known that atherosclerosis is a lipid-driven disease characterized by low-grade chronic inflammation of the arterial wall (34). Targeting of inflammatory processes might be beneficial in attenuating myocardial and arterial injury, reducing disease progression, and promoting healing (35).

Atheromatous plaque development, plaque rupture, and thrombus formation are the main components of this process. Deposition of low-density lipoprotein (LDL) particles in the sub-endothelial layer activates inflammation, causing the attraction of monocytes to atherosclerotic plaque and transformation of monocytes into tissue macrophages $(36,37)$. Macrophages transform into foam cells by phagocytosing lipoprotein particles (36), foam cells maintain inflammation and destabilize the extracellular matrix and endothelial layer (38). As a result of inflammation, procoagulant factors are stimulated, and it also increases the production of plasminogen activator inhibitor 1 (PAI1), one of the main endogenous inhibitors of thrombus and fibrin (39). In this vicious cycle of inflammation, extracellular matrix destruction, and expansive remodeling gradually increase plaque growth and eventually cause acute plaque rupture and acute coronary syndrome (39). C-reactive protein (CRP), fibrinogen, tumor necrosis factor-alpha (TNF- $\alpha$ ), interleukin-1 (IL-1), interleukin-6 (IL-6), interleukin-7 (IL-7), and interleukin-8 (IL-8) levels are high in myocardial infarction or unstable angina $(29,40)$. Chronic low-grade inflammation is a known risk factor for diabetes and cardiovascular disease, which is highly comorbid with depression (41).

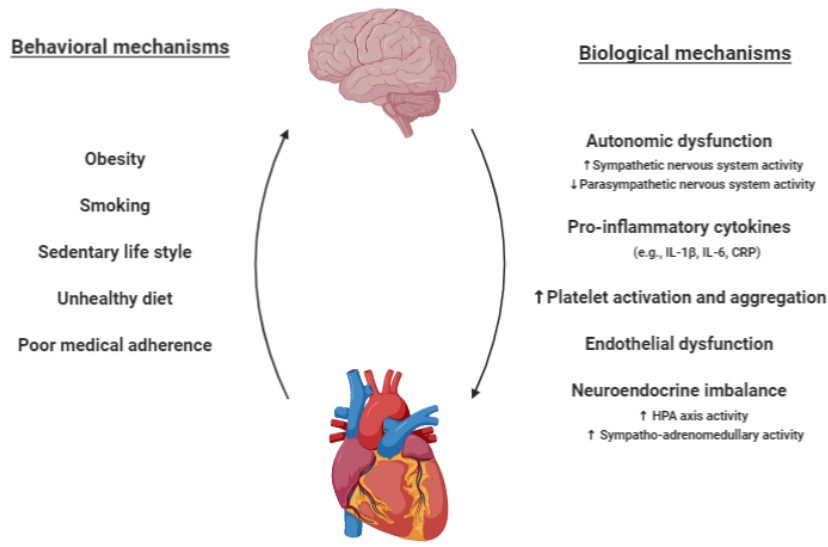

Figure 1. Biological and behavioural mechanisms linking depression and $C V D$ 
The CANTOS study addressed the inflammatory hypothesis in a large cohort of CVD patients, comparing the anti-IL-1 $\beta$ human monoclonal antibody, canakinumab, and placebo (42). Canakinumab provided a $15 \%$ decrease in major cardiovascular events, regardless of LDL levels. However, in another study where inflammation was targeted with lowdose methotrexate, no decrease in IL-1 $\beta$, IL-6, and CRP levels was observed with treatment (43). Anakinra treatment, an IL-1 receptor antagonist, reduced high-sensitivity CRP (hsCRP) levels in patients with acute MI (44).

The accumulating data suggest that cytokines contribute to the pathophysiology of both MDD and CVD, and inflammation is one of the underlying mechanisms in this comorbidity (16, $29,45,46)$.

In 2013, the inflammasome hypothesis of depression and related comorbid systemic diseases has been suggested as a linking pathway by Iwata et al. (47). The Nod-like receptor protein 3 (NLRP3) pathway has been evaluated in the pathogenesis of both MDD and CVD; however, the possible bridge role of NLRP3 in this comorbidity has not been investigated so far (48).

A 20-year cohort study assessed the cardiac events associated with depression and its interaction with hypertension, diabetes, dyslipidemia (49) As a result they stated that the association between depression and a cardiac event cannot be explained by the effects of these other cardiovascular risk factors.

Psychosocial stress is frequently addressed in both CVD and depression. Chronic stress alters the balance in the autonomic nervous system, causes sympathetic system dominance, and decreased vagal tone (29). Decreased vagal tone contributes to a pro-inflammatory status (29). Stress hormones and certain pro-inflammatory substances are released from macrophages and microglia and tryptophan upregulates rate-limiting enzymes in the metabolic pathway. This enzymatic upregulation stimulates the kynurenine pathway and results in the formation of neurotoxic metabolites. Inflammation is already observed in cardiac, cardiovascular, and cerebrovascular pathologies regardless of the presence of depression. Inflammation is closely related to endothelial dysfunction, which is important in atherosclerosis (29).

In recent years, studies have shown that anti-inflammatory treatment strategies including non-steroidal antiinflammatory drugs (NSAIDs), cytokine inhibitors, statins are beneficial in improving symptoms in both CVD and depression (50).

\section{THE POSSIBLE USE OF HS-CRP IN COMORBID DEPRESSION AND CVD}

C-reactive protein (CRP) is a member of the pentraxin family, it is released by hepatocytes largely in response to IL- 6 and other inflammatory cytokines (51). It increases within 4-6 hours after acute tissue damage or inflammation, the halflife is 19 hours and returns to normal levels within days (52).
The normal CRP level in healthy people is below $3 \mathrm{mg} / \mathrm{L}$. While CRP is between 3-10 mg / $\mathrm{L}$ in low-grade inflammation, the levels above $10 \mathrm{mg} / \mathrm{L}$ are generally associated with underlying infection, malignancy, or inflammatory disease (53).

While CRP analyzes can detect above $3 \mathrm{mg} / \mathrm{L}$ levels, hsCRP can detect values as low as $0.1 \mathrm{mg} / \mathrm{L}$ (53). hs-CRP has been studied for CVD for many years and is considered an important marker for cardiovascular risk assessment and treatment decision. Thus, The American Heart Association and the Center for Disease Control and Prevention have recommended the measurement of $h s-C R P$ for screening cardiovascular risk. According to this recommendation, hsCRP $<1 \mathrm{mg} / \mathrm{L}$ is associated with low risk, 1-3 mg / L moderate risk and $>3 \mathrm{mg} / \mathrm{L}$ high risk (54). CRP is not only a predictive marker but also plays a role in the development of the lesion with its pro-inflammatory and pro-atherogenic effects by activating the complement system through complement $\mathrm{C} 1 \mathrm{q}$ and contributes to the destabilization of the fibrotic layer of atheroma and plaque rupture by stimulating the matrix metalloproteinase-1 (MMP-1) by macrophages (52).

A meta-analysis conducted in 2009 showed that IL-1, IL-6, and CRP levels are elevated in patients with depression (55). In a follow-up study with 1794 participants, it was observed that there is a strong relationship between depression and IL-6, CRP, and soluble intercellular adhesion molecule 1 and they predict CVD disease development (56). It is thought that inflammation and depression are risk factors in terms of CVD and hs-CRP has a role in the pathophysiology of CVD and depression, although sometimes inconsistent results have been found in studies. $h s$-CRP is an important inflammatory marker while discussing CVD and depression comorbidity with its common use in cardiology clinics and its increasing importance in psychiatric diseases. A large-scale study demonstrated that psychological stress and depression are associated with increased CRP levels and that higher CRP levels were associated with hospitalization for depression (57).

A prospective study showed that higher CRP levels did not predict depressive episodes; however, it emphasized that higher CRP levels were observed with recurrent depressive episodes (58). A study conducted with 6005 people in Finland, found that Beck Depression Inventory (BDI) scores were correlated with high CRP levels in both men and women (59). In a study examining the relationship between risk factors and inflammatory markers in cardiovascular diseases, in the presence of a diagnosis of depression, $h s-\mathrm{CRP}$ and IL- 6 levels were found to be significantly higher than in patients without a diagnosis of depression (60). A large-scale study showed that depression and anxiety disorders scores were correlated with $h s$-CRP levels, and this relationship was more pronounced in men (61).

After the results were adjusted for other risk factors, such as age, obesity, smoking, body mass index, lipid profile, this relationship remained significant in men but not in women. According to a recent meta-analysis, the prevalence of 
low-grade inflammation (CRP $>3 \mathrm{mg} / \mathrm{L}$ ) in depression is $27 \%$, the prevalence of elevated CRP ( $>1 \mathrm{mg} / \mathrm{L})$ in depression is $58 \%$ (62). Also, higher levels of CRP at baseline are associated with an increased risk of depression in subsequent follow-ups (62). Also, the recent studies found that CRP levels showed a significant decrease with antidepressants $(63,64)$. However, some other meta-analysis has demonstrated no significant effects of antidepressants on CRP levels (65).

\section{CONCLUSION}

Despite the growing amount of literature on the CVD and depression comorbidity, more studies are needed to understand the underlying mechanisms. This is important for screening, early identification, and treatment of comorbid CVD and depression. Also, the initiatives should aim at improving health outcomes in those with CVD and / or depression. hs-CRP, as a well-known biomarker in the cardiology practice, holds promise as a psychiatric biomarker as well. hs-CRP might be useful for identifying the risk groups.

\section{REFERENCES}

[1] Otte C, Gold SM, Penninx BW, Pariante CM, Etkin A, Fava M, Mohr DC, Schatzberg AF. Major depressive disorder. Nat Rev Dis Primers 2016;2(1):16065.

[2] American Psychiatric Association. Diagnostic and Statistical Manual of Mental Disorders, 5th Edition: DSM-5 2013.

[3] Hwang JW, Egorova N, Yang XQ, Zhang WY, Chen J, Yang XY, Hu LJ, Sun S, Tu Y, Kong J. Subthreshold depression is associated with impaired resting-state functional connectivity of the cognitive control network. Transl Psychiatry 2015;5(11):e683-e.

[4] Malhi GS, Mann JJ. Depression. Lancet 2018;392(10161):22992312.

[5] Dean J, Keshavan M. The neurobiology of depression: An integrated view. Asian J Psychiatr 2017;27:101-111.

[6] Correll CU, Solmi M, Veronese N, Bortolato B, Rosson S, Santonastaso P, Thapa-Chhetri N, Fornaro M, Gallicchio D, Collantoni E, Pigato G, Favaro A, Monaco F, Kohler C, Vancampfort D, Ward PB, Gaughran F, Carvalho AF, Stubbs B. Prevalence, incidence and mortality from cardiovascular disease in patients with pooled and specific severe mental illness: a large-scale meta-analysis of 3,211,768 patients and 113,383,368 controls. World Psychiatry 2017;16(2):163-180.

[7] Dahlöf B. Cardiovascular disease risk factors: epidemiology and risk assessment. The Am J Cardiol 2010;105(1 Suppl):3a-9a.

[8] Waldman SA, Terzic A. Cardiovascular health: the global challenge. Clin Pharmacol Ther 2011;90(4):483-5.

[9] Hare DL, Toukhsati SR, Johansson P, Jaarsma T. Depression and cardiovascular disease: a clinical review. Eur Heart J 2014;35(21):1365-72.

[10] Rajan S, McKee M, Rangarajan S, Bangdiwala S, Rosengren A, Gupta R, Kutty VR, Wielgosz A, Lear S, AlHabib KF, Co HU, Lopez-Jaramillo P, Avezum A, Seron P, Oguz A, Kruger IM, Diaz R, Nafiza MN, Chifamba J, Yeates K, Kelishadi R, Sharief WM, Szuba A, Khatib R, Rahman O, Iqbal R, Bo H, Yibing Z, Wei L, Yusuf S. Association of symptoms of depression with cardiovascular disease and mortality in low-, middle-, and highincome countries. JAMA Psychiatry 2020;77(10):1052-1063.
[11] Celano CM, Huffman JC. Depression and cardiac disease: a review. Cardiol Rev 2011;19(3):130-42.

[12] Case SM, Sawhney M, Stewart JC. Atypical depression and double depression predict new-onset cardiovascular disease in U.S. adults. Depress Anxiety 2018;35(1):10-17.

[13] Lichtman JH, Froelicher ES, Blumenthal JA, Carney RM, Doering LV, Frasure-Smith N, Freedland KE, Jaffe AS, Leifheit-Limson EC, Sheps DS, Vaccarino V, Wulsin L; American Heart Association Statistics Committee of the Council on Epidemiology and Prevention and the Council on Cardiovascular and Stroke Nursing. Depression as a risk factor for poor prognosis among patients with acute coronary syndrome: systematic review and recommendations: a scientific statement from the American Heart Association. Circulation 2014;129(12):1350-69.

[14] Van der Kooy K, van Hout H, Marwijk H, Marten H, Stehouwer C, Beekman A. Depression and the risk for cardiovascular diseases: systematic review and meta analysis. Int J Geriatr Psychiatry 2007;22(7):613-26.

[15] Jha MK, Qamar A, Vaduganathan M, Charney DS, Murrough JW. Screening and management of depression in patients with cardiovascular disease: JACC State-of-the-Art Review. J Am Coll Cardiol 2019;73(14):1827-1845.

[16] Carney RM, Freedland KE. Depression and coronary heart disease. Nat Rev Cardiol 2017;14(3):145-155.

[17] Wynn A. Unwarranted emotional distress in men with ischaemic heart disease (IHD). Med J Aust 1967;2(19):847-51.

[18] Anda R, Williamson D, Jones D, Macera C, Eaker E, Glassman A, Marks J. Depressed affect, hopelessness, and the risk of ischemic heart disease in a cohort of U.S. adults. Epidemiology 1993:285-94.

[19] Yusuf S, Hawken S, Ounpuu S, Dans T, Avezum A, Lanas F, McQueen M, Budaj A, Pais P, Varigos J, Lisheng L; INTERHEART Study Investigators. Effect of potentially modifiable risk factors associated with myocardial infarction in 52 countries (the INTERHEART study): case-control study. Lancet 2004;364(9438):937-52.

[20] Wulsin LR, Evans JC, Vasan RS, Murabito JM, Kelly-Hayes M, Benjamin EJ. Depressive symptoms, coronary heart disease, and overall mortality in the Framingham Heart Study. Psychosom Med 2005;67(5):697-702.

[21] Thombs BD, Bass EB, Ford DE, Stewart KJ, Tsilidis KK, Patel $U$, Fauerbach JA, Bush DE, Ziegelstein RC. Prevalence of depression in survivors of acute myocardial infarction. J Gen Intern Med 2006;21(1):30-8.

[22] Janszky I, Ahlbom A, Hallqvist J, Ahnve S. Hospitalization for depression is associated with an increased risk for myocardial infarction not explained by lifestyle, lipids, coagulation, and inflammation: the SHEEP Study. Biol Psychiatry 2007;62(1):2532.

[23] Holahan CJ, Pahl SA, Cronkite RC, Holahan CK, North RJ, Moos $\mathrm{RH}$. Depression and vulnerability to incident physical illness across 10 years. J Affect Disord 2010;123(1-3):222-9.

[24] Nabi H, Kivimäki M, Empana JP, Sabia S, Britton A, Marmot MG, Shipley MJ, Singh-Manoux A. Combined effects of depressive symptoms and resting heart rate on mortality: the Whitehall II prospective cohort study. J Clin Psychiatry 2011;72(9):1199206.

[25] Nemeroff CB, Goldschmidt-Clermont PJ. Heartache and heartbreak - the link between depression and cardiovascular disease. Nat Rev Cardiol 2012;9(9):526-39. 
[26] Gan Y, Gong Y, Tong X, Sun H, Cong Y, Dong X, Wang Y, Xu X, Yin $X$, Deng J, Li L, Cao S, Lu Z. Depression and the risk of coronary heart disease: a meta-analysis of prospective cohort studies. BMC Psychiatry 2014;14:371.

[27] Mannie ZN, Williams C, Diesch J, Steptoe A, Leeson P, Cowen PJ. Cardiovascular and metabolic risk profile in young people at familial risk of depression. Br J Psychiatry. 2013;203(1):1823.

[28] Khandaker GM, Zuber V, Rees JMB, Carvalho L, Mason AM, Foley CN, Gkatzionis A, Jones PB, Burgess S. Shared mechanisms between coronary heart disease and depression: findings from a large UK general population-based cohort. Mol Psychiatry 2019;25(7):1477-1486.

[29] Halaris A. Inflammation-associated co-morbidity between depression and cardiovascular disease. Curr Top Behav Neurosci 2017;31:45-70.

[30] Dantzer R, O'Connor JC, Freund GG, Johnson RW, Kelley KW. From inflammation to sickness and depression: when the immune system subjugates the brain. Nat Rev Neurosci 2008;9(1):46-56.

[31] Haapakoski R, Mathieu J, Ebmeier KP, Alenius H, Kivimäki M. Cumulative meta-analysis of interleukins 6 and $1 \beta$, tumour necrosis factor $\alpha$ and $C$-reactive protein in patients with major depressive disorder. Brain Behav Immun 2015;49:206-15.

[32] Dowlati Y, Herrmann N, Swardfager W, Liu H, Sham L, Reim EK, Lanctôt KL. A meta-analysis of cytokines in major depression. Biol Psychiatry 2010;67(5):446-57.

[33] Hansson GK. Inflammation, atherosclerosis, and coronary artery disease. N Engl J Med 2005;352(16):1685-95.

[34] Bäck M, Yurdagul A Jr, Tabas I, Öörni K, Kovanen PT. Inflammation and its resolution in atherosclerosis: mediators and therapeutic opportunities. Nat Rev Cardiol 2019;16(7):389406.

[35] Ruparelia N, Chai JT, Fisher EA, Choudhury RP. Inflammatory processes in cardiovascular disease: a route to targeted therapies. Nat Rev Cardiol 2017;14(3):133-144.

[36] Geovanini GR, Libby P. Atherosclerosis and inflammation: overview and updates. Clin Sci (Lond) 2018;132(12):1243-52.

[37] Soysal P, Arik F, Smith L, Jackson SE, Isik AT. Inflammation, frailty and cardiovascular disease. Adv Exp Med Biol 2020;1216:5564.

[38] Nahrendorf M, Swirski FK. Innate immune cells in ischaemic heart disease: does myocardial infarction beget myocardial infarction? Eur Heart J 2016;37(11):868-72.

[39] Vogel B, Claessen BE, Arnold SV, Chan D, Cohen DJ, Giannitsis E, Gibson CM, Goto S, Katus HA, Kerneis M, Kimura T, Kunadian V, Pinto DS, Shiomi H, Spertus JA, Steg PG, Mehran R. STsegment elevation myocardial infarction. Nat Rev Dis Primers 2019;5(1):39.

[40] Lind L. Circulating markers of inflammation and atherosclerosis. Atherosclerosis. 2003;169(2):203-14.

[41] Herman FJ, Pasinetti GM. Principles of inflammasome priming and inhibition: Implications for psychiatric disorders. Brain Behav Immun 2018;73:66-84.

[42] Ridker PM, Everett BM, Thuren T, MacFadyen JG, Chang WH, Ballantyne C, Fonseca F, Nicolau J, Koenig W, Anker SD, Kastelein JJP, Cornel JH, Pais P, Pella D, Genest J, Cifkova R, Lorenzatti A, Forster T, Kobalava Z, Vida-Simiti L, Flather M, Shimokawa H, Ogawa H, Dellborg M, Rossi PRF, Troquay RPT, Libby P,Glynn RJ; CANTOS Trial Group. Antiinflammatory therapy with canakinumab for atherosclerotic disease. N Engl J Med 2017;377(12):1119-1131.

[43] Ridker PM, Everett BM, Pradhan A, MacFadyen JG, Solomon $\mathrm{DH}$, Zaharris E, Mam V, Hasan A, Rosenberg $\mathrm{Y}$, Iturriaga E, Gupta M, Tsigoulis M, Verma S, Clearfield M, Libby P, Goldhaber SZ, Seagle R, Ofori C, Saklayen M, Butman S, Singh N, Le May M, Bertrand O, Johnston J, Paynter NP, Glynn RJ, CIRT Investigators. Low-dose methotrexate for the prevention of atherosclerotic events. N Engl J Med 2019;380(8):752-762.

[44] Abbate A, Van Tassell BW, Biondi-Zoccai G, Kontos MC, Grizzard JD, Spillman DW, Oddi C, Roberts CS, Melchior RD, Mueller GH, Abouzaki NA, Rengel LR, Varma A, Gambill ML, Falcao RA, Voelkel NF, Dinarello CA, Vetrovec GW. Effects of interleukin-1 blockade with anakinra on adverse cardiac remodeling and heart failure after acute myocardial infarction [from the Virginia Commonwealth University-Anakinra Remodeling Trial (2) (VCU-ART2) pilot study]. Am J Cardiol 2013;111(10):1394400.

[45] Mattina GF, Van Lieshout RJ, Steiner M. Inflammation, depression and cardiovascular disease in women: the role of the immune system across critical reproductive events. Ther Adv Cardiovasc Dis 2019;13:175.394.4719851950.

[46] Fioranelli M, Bottaccioli AG, Bottaccioli F, Bianchi M, Rovesti M, Roccia MG. Stress and inflammation in coronary artery disease: A review psychoneuroendocrineimmunology-based. Front Immunol 2018;9:2031.

[47] Iwata M, Ota KT, Duman RS. The inflammasome: pathways linking psychological stress, depression, and systemic illnesses. Brain Behav Immun 2013;31:105-14.

[48] Alcocer-Gomez E, Cordero MD. NLRP3 inflammasome: common nexus between depression and cardiovascular diseases. Nat Rev Cardiol 2017;14(2):124.

[49] Hamieh N, Meneton P, Wiernik E, Limosin F, Zins M, Goldberg M, Melchior M, Lemogne C. Depression, treatable cardiovascular risk factors and incident cardiac events in the Gazel cohort. Int J Cardiol 2019;284:90-95.

[50] Zuzarte P, Duong A, Figueira ML, Costa-Vitali A, Scola G. Current Therapeutic Approaches for Targeting Inflammation in Depression and Cardiovascular Disease. Curr Drug Metab 2018;19(8):674-87.

[51] Del Giudice M, Gangestad SW. Rethinking IL-6 and CRP: Why they are more than inflammatory biomarkers, and why it matters. Brain Behav Immun 2018;70:61-75.

[52] Castro AR, Silva SO, Soares SC. The use of high sensitivity C-reactive protein in cardiovascular disease detection. J Pharm Pharm Sci 2018;21(1):496-503.

[53] Windgassen EB, Funtowicz L, Lunsford TN, Harris LA, Mulvagh SL. C-reactive protein and high-sensitivity C-reactive protein: an update for clinicians. Postgrad Med 2011;123(1):114-9.

[54] Pearson TA, Mensah GA, Alexander RW, Anderson JL, Cannon RO 3rd, Criqui M, Fadl YY, Fortmann SP, Hong Y, Myers GL, Rifai N, Smith SC Jr, Taubert K, Tracy RP, Vinicor F, Centers for Disease Control and Prevention and the American Heart Association. Markers of inflammation and cardiovascular disease: application to clinical and public health practice: A statement for healthcare professionals from the Centers for Disease Control and Prevention and the American Heart Association. Circulation 2003;107(3):499-511.

[55] Howren MB, Lamkin DM, Suls J. Associations of depression with C-reactive protein, IL-1, and IL-6: a meta-analysis. Psychosom Med 2009;71(2):171-86. 
[56] Davidson KW, Schwartz JE, Kirkland SA, Mostofsky E, Fink D, Guernsey D, Shimbo D. Relation of inflammation to depression and incident coronary heart disease (from the Canadian Nova Scotia Health Survey [NSHS95] Prospective Population Study). Am J Cardiol 2009;103(6):755-61.

[57] Wium-Andersen MK, Ørsted DD, Nielsen SF, Nordestgaard BG. Elevated C-reactive protein levels, psychological distress, and depression in 73131 individuals. JAMA Psychiatry 2013;70(2):176-84.

[58] Copeland WE, Shanahan L, Worthman C, Angold A, Costello EJ. Cumulative depression episodes predict later C-reactive protein levels: a prospective analysis. Biol Psychiatry 2012;71(1):15-21.

[59] Elovainio $M$, Aalto $A M$, Kivimäki $M$, Pirkola $S$, Sundvall J, Lönnqvist J, Reunanen A. Depression and C-reactive protein: population-based Health 2000 Study. Psychosom Med 2009;71(4):423-30.

[60] Nadrowski P, Chudek J, Skrzypek M, Puzianowska-Kuźnicka M, Mossakowska M, Więcek A, Zdrojewski T, Grodzicki T, Kozakiewicz K. Associations between cardiovascular disease risk factors and IL-6 and hsCRP levels in the elderly. Exp Gerontol 2016;85:112-117.

[61] Tayefi M, Shafiee M, Kazemi-Bajestani SMR, Esmaeili H, Darroudi S, Khakpouri S, Mohammadi M, Ghaneifar Z,
Azarpajouh MR, Moohebati M, Heidari-Bakavoli A, Parizadeh MR, Nematy M, Safarian M, Ebrahimi M, Ferns GA, Mokhber N, Ghayour-Mobarhan M. Depression and anxiety both associate with serum level of hs-CRP: a gender-stratified analysis in a population-based study. Psychoneuroendocrinology 2017;81:63-69.

[62] Osimo EF, Baxter LJ, Lewis G, Jones PB, Khandaker GM. Prevalence of low-grade inflammation in depression: a systematic review and meta-analysis of CRP levels. Psychol Med 2019;49(12):1958-1970.

[63] Hiles SA, Baker AL, de Malmanche T, Attia J. Interleukin-6, C-reactive protein and interleukin-10 after antidepressant treatment in people with depression: a meta-analysis. Psychol Med 2012;42(10):2015-26.

[64] Eyre HA, Lavretsky H, Kartika J, Qassim A, Baune BT. Modulatory effects of antidepressant classes on the innate and adaptive immune system in depression. Pharmacopsychiatry 2016;49(3):85-96.

[65] Więdłocha $M$, Marcinowicz $P$, Krupa R, Janoska-Jaździk $M$, Janus M, Dębowska W, Mosiołek A, Waszkiewicz N, Szulc A. Effect of antidepressant treatment on peripheral inflammation markers - A meta-analysis. Prog Neuropsychopharmacol Biol Psychiatry 2018;80(Pt C):217-226. 